\title{
Biological and molecular characterization of six Shiga toxin-producing Escherichia coli (STEC) strains encoding the stx2 gene in Colombia
}

\section{Brayan Stiven Arango-Gil ${ }^{1 *}$, Sebastián Peña-Buitrago ${ }^{1}$, Jhon Carlos Castaño-Osorio1, Claudia Viviana Granobles-Velandia ${ }^{1}$ \\ *e-mail: bsarangog@uqvirtual.edu.co}

${ }^{1}$ Molecular Immunology Group (GYMOL), "Manuel Elkin Patarroyo" Biomedical Research Center, Universidad del Quindío. Armenia, Quindío, Colombia.

\begin{abstract}
Shiga toxin-producing Escherichia coli (STEC) is a bacterial pathogen that cause diarrhea and severe human diseases. Its principal virulence factor are the Shiga toxins Stx1 and Stx2 which have been identified diverse subtypes considered to be responsible for severe complications of STEC infection. These toxins are encoded in temperate bacteriophages and their expression is linked to phage lithic cycle, which is regulated by late genes and the $\mathrm{Q}$ anti-terminator protein. The aim of this study was to characterize biologically and molecularly STEC strains encoding stx 2 gene isolated from cattle feces in Colombia. We selected six STEC strains, which were evaluated its Stx production, the $\mathrm{Stx}_{2}$ subtypes, induction of the lithic cycle of bacteriophages and its late region. The results evidenced two highlighted strains with high levels of Stx production and induction of the lithic cycle, compared with the others. Likewise, the strains evaluated showed three Stx 2 subtypes: $\mathrm{Stx}_{2} \mathrm{a}, \mathrm{Stx}_{2} \mathrm{c}$, and $\mathrm{Stx}_{2} \mathrm{~d}$. Regarding the late region, most of the strains carried the $q 0111$ allele and only one strain showed differences in the $\operatorname{nin} G$ gene. Although the sample was limited, variability was observed in the Stx production assay, induction of the lithic cycle, Stx 2 subtypes and late region of the phages, which could indicate the diversity of the phages carrying STEC strains in Colombia.
\end{abstract}

KEY WORDS: STEC, bacteriophages, Shiga toxin, bovine, HUS

\section{INTRODUCTION}

Shiga toxin-producing Escherichia coli (STEC), is an emerging pathogen involved in food-borne infections which causes diarrheal disease outbreaks, like hemorrhagic colitis (HC) and hemolytic uremic syndrome (HUS). The HUS is one of the most severe human disease caused for STEC, characterized for producing thrombocytopenia and acute kidney failure, which mainly affect children under 5 years old and older adults [1]. Cattle have been considered the main reservoir of pathogenic STEC for humans and its transmission occurs through the consumption of contaminated foods with feces from cattle, like meats, cheese, and unpasteurized milk. Also, there are other pathways of transmission, like intake of contaminated water, fruits, and vegetables, causing outbreaks of STEC infection [2]. 
The main virulence factors of STEC associated with HUS are Shiga toxins (Stx). The Stx are $\mathrm{AB}_{5}$ toxins, composed of one A subunit and five identical B subunits, which links the toxin to a glycolipid receptor, Gb3 or Gb4, on the surface of the target cells, such as kidney cells, the gastrointestinal tract and central nervous system cells. There are two types of Stx: Stx1 and Stx2, which share approximately $56 \%$ of homology in their amino acid sequence. However, Stx 2 has been linked epidemiologically to the development of severe diseases, like HUS [3]. Studies on human brain microvascular endothelial cells (HBMC) have shown to be until 1000 times more susceptible to Stx2 than to Stx1 [4], for this reason Stx2 has received greater research attention.

It has been described seven subtypes or genetic variants of Stx2, being Stx2a, Stx2c, and Stx2d the subtypes with the greatest toxicity in vitro and the most commonly subtypes identified in STEC strains isolated from patients with clinical manifestations of HUS, unlike the Stx2b, Stx2e, Stx2f and Stx2g subtypes, which have low toxicity and rarely associated with severe diseases in humans, that have been found in animal reservoirs different from cattle like pigs and pigeons [5-6]. The amino acid sequences of the Stx2a, Stx2c, and Stx2d subtypes are closely related, sharing an identity percentage between $97 \%$ and $99 \%$, but due to their biological differences and toxicity, they have been classified as different subtypes [7].

The Shiga toxin genes (stx) are encoded by temperate bacteriophages inserted in the bacteria chromosome, phages encoding stx (stx phages) have shown to be variables both morphologically and genetically and play an important role in STEC pathogenesis due they can regulate Stx expression and contribute to the dissemination of the stx genes in other bacteria [8]. The stx genes are located in the late region of the stx phages where genes implicated in the lithic cycle are found. Likewise, late genes are regulated by a transcription anti-terminator protein Q. In absence of the $\mathrm{Q}$ protein, the phages cannot carry out their lithic cycle, which implies they will not produce Stx [9]. For the Q protein gene have been identified three allelic variants: $q 933, q 21$, and $q 0111$, which are related with differences on the levels of expression of the Stx and virulence of the strains that carrying them [10-12].

In Colombia, the knowledge about STEC is limited and the few studies available have focused on detecting the O157:H7 serotype from different sources and with non-molecular methods [13-14], in addition, no characterization is available of the native strains that have been isolated, either is known their potential virulence. which is why the objective of this work was to characterize biologically and molecularly STEC strains carriers of the $\mathrm{stx}_{2}$ gene isolated from bovine cattle in Colombia to provide information on the STEC strains circulating in Colombia, and have an idea of its potential virulence. 


\section{MATERIALS and METHODS}

\section{Bacterial strains.}

This study was a descriptive cross-sectional, we selected six cattle STEC strains (102, 10610, 600 5052,615 , and N108) positive for the stx 2 gene belonging to the collection of strains from the Center of Biomedical Research at Universidad del Quindío. These strains had been characterized previously respect to the presence-absence of STEC virulence genes (stx, eae, saa, and hlyA) (Table 1) (Quiguanas et al 2020, not published). The STEC reference strain EDL933 was used as positive control and the E. coli DH5 $\alpha$ strain was used as negative control.

\section{Induction of the lithic cycle.}

All the strains were grown individually in Luria-Bertani (LB) broth overnight (ON) at $37{ }^{\circ} \mathrm{C}, 100$ $\mathrm{rpm}$. These cultures were refreshed in LB medium at $37^{\circ} \mathrm{C}, 180 \mathrm{rpm}$, when the culture reached the exponential growth phase (Optical Density $\mathrm{OD}_{600}=0.2-0.3 \mathrm{~nm}$ ), it was divided into two subcultures and Mitomycin C (MMC) was added to a fraction at a final concentration of $0.5 \mu \mathrm{g} / \mathrm{ml}$ (inducer of the lithic cycle). The $\mathrm{OD}_{600}$ of the cultures both with and without MMC was monitored during five hours to construct growth curves/lysis, growth was measure with a Microplate Spectrophotometer Epoch ${ }^{\mathrm{TM}}$ (BioTek). All assays were done at least three times and independently for each strain.

\section{Stx 2 production}

To compare the titers of Stx2, the cultures with and without MMC after overnight incubation at 37 ${ }^{\circ} \mathrm{C}, 180 \mathrm{rpm}$ were centrifuged at $11.500 \mathrm{rpm}, 4{ }^{\circ} \mathrm{C}$ during $10 \mathrm{~min}$ and the supernatants were evaluated for the presence of Stx2 using an ELISA kit (Ridascreen ${ }^{\circledR}$ Verotoxin, R-Biopharm) according to the manufacturer's instructions. The ELISA plates were read in the Microplate Spectrophotometer Epoch ${ }^{\mathrm{TM}}$ (BioTek) at $\mathrm{DO}_{650}$. However, when the $\mathrm{DO}_{650}$ values exceeded the limit permitted by the Epoch $^{\mathrm{TM}}$ (BioTek), serial dilutions were conducted to obtain a value within the equipment's reading range. The toxin titers were expressed as the result of the multiplication between the $\mathrm{DO}_{650}$ and the reciprocal of the dilution factor; all the assays were carried out at least three times.

\section{Analysis of the late region of stx phages}

The upstream region of the $s t x_{2}$ gene was analyzed by PCR in Veriti 96-Well Thermal Cycler (Applied Biosystems ${ }^{\mathrm{TM}}$ ). The proximity of the ninG gene with $s t x_{2}$ was evaluated using NinG/526 and 595 primers [15], the variability in this gene was evaluated by comparing the sizes of the amplified fragments. The presence of the different alleles of $q$ gene $(q 933, q 0111$, and $q 21)$ was 
evaluated in all of the strains as well as its closeness with the $s t x_{2}$ gene. To detect the $q 933$ allele, the QATG5' and Q3' primers were used [16], and the closeness with the stx 2 gene was evaluated using the Q-stX-f and 595 primers [15]. The presence of the qO111 allele was evaluated with the SF1-F and SF1-R primers [12] and its closeness with the $s t x_{2}$ gene was evaluated with the SF1-F and 595 primers. The $q 21$ allele and its closeness with the stx 2 gene was evaluated with the Q21 and 595 primers [11] (Fig.1). All the primers used here are shown in Table 2. The conditions for the PCR were the following: $94{ }^{\circ} \mathrm{C}$ for $5 \mathrm{~min}$, followed by 30 cycles of $94{ }^{\circ} \mathrm{C}$ for $1 \mathrm{~min}, 60{ }^{\circ} \mathrm{C}$ for $1 \mathrm{~min}, 72{ }^{\circ} \mathrm{C}$ for $3 \mathrm{~min}$, ending with $72{ }^{\circ} \mathrm{C}$ for $10 \mathrm{~min}$. For the QATG5' and Q3 primers annealing temperature was $53{ }^{\circ} \mathrm{C}$.

\section{Identification of Stx2 subtypes}

The identification of Stx 2 subtypes was performed through analysis of sequences with the method proposed by Persson et al [17] and Scheutz et al [7]. A partial sequence of $s t x_{2}$ gene was obtained by using the F4 and R1 sequencing primers (Table 2), these primers amplifying a $491 \mathrm{pb}$ fragment which was translated into 159 amino acids covering 95 residues from the $\mathrm{C}$-terminal region of the A subunit and 64 residues from the N-terminal region of the B subunit, where the sequences of the toxins have greater variability. The PCRs were performed with the Platinum ${ }^{\mathrm{TM}}$ Taq DNA Polymerase High Fidelity kit $\left(\right.$ Invitrogen $^{\mathrm{TM}}$ ) with the following conditions: $95{ }^{\circ} \mathrm{C}$ for $15 \mathrm{~min}$, followed by 35 cycles at $94{ }^{\circ} \mathrm{C}$ for $50 \mathrm{~s}, 56{ }^{\circ} \mathrm{C}$ for $40 \mathrm{~s}$, and $72{ }^{\circ} \mathrm{C}$ for $1 \mathrm{~min}$, and an ending temperature of $72{ }^{\circ} \mathrm{C}$ for $3 \mathrm{~min}$. the amplicons obtained with forward and reverse PCR primers were sequenced with the Sanger method in an ABI3500 (Applied Biosystems ${ }^{\mathrm{TM}}$ ). The DNA used for the different PCRs were purified by using the Wizard ${ }^{\circledR}$ Genomics Kit (Promega).

The consensus sequences were obtained with the forward and reverse chromatograms using the Unipro software UGENE RRID: SCR_005579. To identify the subtypes, the intergenic regions between $\mathrm{A}$ and $\mathrm{B}$ subunits of stx 2 sequences of all strains were compared. The nucleotide sequences were translated into amino acids with the ORF established for Stx2 (excluding the intergenic region). A multiple alignment with the amino acid sequences obtained and reference sequences for Stx2 subtypes was carried out by employing the MEGA7 software RRID:SCR_000667 and the Muscle algorithm. Conserved positions described in the literature for each subtype were examined in the multiple alignment; the accession codes for the reference sequences used in the alignment were: Stx2a (GenBank ID: Z37725) Stx2c (GenBank ID: L11079) Stx2d (GenBank ID:DQ059012).

The partial sequences obtained were used to construct a dendrogram by using the UPGMA algorithm (bootstrap of 1000) with various reference sequences of Stx2 subtypes register in the GenBank database: X07865; Z37725; AF524944; AF461173; AY633471; AY633472; EF441599; EF441609; AY443052; AY443057; EF441613; Z50754; DQ344636; FM998856; EF441618; M59432; AB015057; DQ235774; L11079; AY633473; AY443045; AY633467; AY633453; 
AF291819; EF441604; AY739670; AY739671; AY443044; AY443043; AY443049; AB071845; FM998860; FM177471; EU086525; AF479828; AF479829; AY095209; X61283; DQ235775; AF500190; AF500189; AF500191; AY443047; AY443048; DQ059012; AF329817; AF500192; FM998855; FM998840; EF441605; M21534; AJ313016; M29153; AB472687; AY286000; AB048227; X65949. Although the sequences of the reference strains were complete sequences, in order to perform the analysis, these sequences were cut in the region shown in the alignment (Fig. 4A). The sequences obtained in this study were deposited in the GenBank with the following access numbers: MT680394; MT680395; MT680396; MT680397; MT680398; MT680399.

\section{RESULTS}

\section{Induction of the lithic cycle}

Analysis of growth curves showed that all the cultures without MMC had exponential growth with $\mathrm{OD}_{600}$ values of \pm 1.4 , the same behavior was observed with the positive and negative control cultures: EDL933 and DH5 $\alpha$. However, upon inducing the phages with MMC was observed that the 10610 strain had a clear decrease of OD $_{600}$ since the third hour evidencing bacteriolysis by the phage induction. A similar pattern was observed in the 600 strain, but with less decreasing in $\mathrm{OD}_{600}$. In the rest of the strains $(102,5052,615$, and N108) MMC caused a decrease in bacterial growth, without evidence of bacteriolysis by phages induction, showing a growth with values of $\mathrm{OD}_{600} \pm 0.8$ (Fig. 2).

\section{Shiga toxin production}

All the strains evaluated showed Stx2 production; nevertheless, the titers obtained were different among each other. The 10610 strain showed higher Stx production presenting similar titers to the positive control strain. The 5052, 600, and N108 strains showed lower titers than the control strain, but with moderate Stx production. The 102 and 615 strains produced the lowest titers compared with the other strains (Fig. 3). In general, all the strains revealed an increase in the toxin titers when the cultures were induced with MMC. We observed that under non-induction conditions Stx was also detected, but always with low titers, which would demonstrate a basal toxin production in all the strains. The results of absorbance and dilutions carried out are shown in Table S1.

\section{Analysis of the late region of stx phages}

The proximity of the $\operatorname{nin} G$ gene with the $s t x_{2}$ gene was confirmed in all the strains, where an amplified of $1700 \mathrm{pb}$ fragment was observed, except for the N108 strain that obtained a fragment of $1200 \mathrm{pb}$ suggesting a possible difference in the regulating region of these phages. Regarding the $q$ gene alleles, the $q 933$ allele was detected in all the strains, however, upon evaluating its closeness with the $s t x_{2}$ gene an amplified was not obtained. With respect to the $q 0111$ allele, its 
presence and closeness with the stx 2 gene were confirmed in five strains. None of the strains studied carried the $q 21$ allele, the results are shown in Table 3.

\section{Identification of Stx2 subtypes}

The chromatograms of some strains showed that in specific positions there were double peaks that corresponded to different nucleotides, in these cases, the IUPAC nucleotide nomenclature was used for resolve these ambiguities. Once the consensus sequence was obtained and translating it into amino acids, it was noted that in most cases the ambiguities in the nucleotides from these positions did not alter the amino acid in the sequence (synonymous mutations); only in two cases (10610 and 600 strains) we observed a codon change in the position 137 and it could be translated into two different amino acids: Alanine or Aspartic acid (Fig. 4A).

Analysis of the intergenic region between the A and B subunit genes of Stx2, showed that all the strains had the same sequence (AGGAGTTAAGT); this sequence has been reported for the Stx2a, Stx2c, and Stx2d subtypes. Analyzing the alignment, we observed that all subtypes sequences were highly conserved and only differ in some positions (Fig. 4A) the combination of these positions were used to classify the subtypes, obtaining the following results: Stx2a subtype; one strain, Stx2c subtype; three strains and Stx2d subtype; two strains. Specific changes were observed in amino acid residues in some sequences; however, these are not strictly restricted to a subtype. In the dendrogram both the studied and the reference sequences formed separate groups confirming what was observed in the alignment (Fig. 4B),

\section{DISCUSSION}

Presence of inducible phages in the strains studied was evaluated through the analysis of the growth curves/lysis, where it was noted that two of them (10610 and 600) showed bacteriolysis by phage induction with MMC. Likewise, the cultures of these two strains also had the highest Stx titers together with the 5052 strain under induced conditions. Which demonstrates that these strains have phages capable of producing Stx, even at the positive control level. Various studies have shown that the STEC strains with inducible stx phages when were treated with MMC increase substantially Stx production, evidencing a direct relationship between induction and Stx production [18-22]. Additionally, Ogura et al [23] have proposed that variability in Stx production among STEC strains may be related with the genetic characteristics of the phages that carry them.

On the contrary, analysis of the growth curves/lysis of the 102 and 615 strains showed a different behavior; both had low response to induction and low Stx titers, even under induced conditions. It has been demonstrated that bacteria can have a high frequency of defective prophages [24-25], which are not capable of carrying out its lithic cycle, limiting its capacity to kill the host bacterial cell; therefore, this would avoid (in the case of stx phages) Stx production. Similarly, Johansen et 
al [26] suggest that the level of Stx production in bacteria carrying apparently defective phages is lower than bacteria carrying inducible phages. In this sense, the low Stx production in the 102 and 615 strains may be explained by the lack of stx phage induction observed through the OD kinetics, which could be due to the presence of a defective $s t x_{2}$-phage.

Additionally, in this study we detected Stx production in cultures without MMC, which demonstrates that the strains have a basal expression. In agreement with our results, Gamage et al [27] by analyzing pure supernatants, also reported that all stx 2 strains produced high toxin levels, both in presence and in absence of treatments that induce the phage's lithic cycle. Probably, the high Stx production under basal conditions is due to a high level of spontaneous induction of the phage that leading to elevated release of Stx. Shimizu et al [28] reported that some stx phages have a relatively high spontaneous induction, which results in the presence of Stx2 in the extracellular fraction in absence of any applied induction.

It has been described three alleles encoding for the Q protein $(q 933, q 0111$ and $q 21)$, which differ in their activity as anti-terminators [10-12]. In this study we detected the $q 0111$ allele in five strains $(102,10610,5052,615$, and N108), except the 600 strain. This allele was described recently in Sorbitol-fermenting STEC strains isolated from patients with diarrheic diseases and HUS in several European countries [29-30, 12] which have been related with high progression to HUS [31]. In this study was not possible to demonstrate the closeness of the $q 933$ allele with the stx 2 genes. Perhaps, $q$ gene detection in those strains may be due to the presence of defective phages that lack stx genes. Regarding the $q 21$ allele, none strain was found carrying this allele, which has been identified principally in STEC strains with low or null Stx production frequently isolated from beef, animal origin, and the environment in Asian countries, where these are widely distributed [32-34, 10].

Subtyping the STEC strains permitted identifying three Stx2 subtypes: one Stx2a-positive strain, three Stx2c-positive strains and two Stx2d-positive strains, as well as their possible virulence. According to Kawano et al and Fierz et al $[35,5]$ the STEC strains carriers of these three subtypes have been frequently isolated from patients with HUS, which has led to be strongly related with this disease. The most relevant subtypes identified were: the Stx2a, according to the literature it has demonstrated to be the most potent and active on the endothelial cells $[4,6]$ and the Stx2d, due to an "the activable tail" that causes an increase of up to 25 times its toxicity on Vero cells when it is previously incubated with elastases [36].

Although the three subtypes share a high percentage of identity regarding their amino acid sequence, differences were found in positions 89,95 on the end of C-terminal of the A subunit and in the END or EDD motif in the B subunit. Fuller et al [6] suggest that the END motif of the B subunit plays an important role in the interaction of the toxin with its receptor, therefore mutations in these positions would cause changes in the affinity of the toxin with his receptor, which could explain the toxicity differences existing among these subtypes. Finally, in the evaluated strains the 
Stx2b, Stx2e, Stx2g, and Stx2f subtypes were not identified; these subtypes are rarely associated with diseases in humans and contrary to the other subtypes, they have been isolated from sources different from cattle like pigs and pigeons, for that reason they were not detected in this study, due to all the strains were from cattle [37-38].

\section{CONCLUSION}

The results obtained in this study show that the native STEC strains evaluated had differences in the Stx production assays, induction of the phage's lithic cycle, Stx 2 subtypes, and late region of the stx phages. Although the sample was limited, it was possible to observe variability among the strains, which could indicate the diversity of the phages carrying the STEC strains in Colombia. Finally, the strains characteristics found in this study are similar to STEC strains that cause diseases in humans reported in the literature. This permit having an idea of the possible virulence of the native STEC, however, more studies are necessary with broader samples that permit determining their virulence in depth.

\section{KNOWLEDGES}

The authors acknowledge to financial support through The Universidad del Quindío through the internal call $\mathrm{N}^{\circ} 5$, project $\mathrm{N}^{\circ} 890$.

\section{BIBLIOGRAPHY}

1. Obrig T (2010) Escherichia coli Shiga toxin mechanisms of action in renal disease. Toxins 2:2769-2794. DOI:10.3390/toxins2122769

2. Persad A, Lejeune J (2015) Animal Reservoirs of Shiga Toxin-Producing Escherichia coli. In: Sperandio V, Hovde C editors. Enterohemorrhagic Escherichia Coli and Other Shiga Toxin-Producing E. Coli. Washington DC. ASM Press. pp. 231-244.

3. Johannes L, Römer, W (2010) Shiga toxins - from cell biology to biomedical applications. Nat. Rev. Microbiol 8:105-116. DOI:10.1038/nrmicro2279

4. Bauwens A, Bielaszewska M, Kempe, B, et al (2011) Differential cytotoxic actions of Shiga toxin 1 and Shiga toxin 2 on microvascular and macrovascular endothelial cells. Thromb Haemost 105:515-528. DOI:10.1160/TH10-02-0140

5. Kawano K, Okada M, Haga T et a 1 (2008) Relationship between pathogenicity for humans and stx genotype in Shiga toxin-producing Escherichia coli serotype O157. Eur J Clin Microbiol Infect Dis 27: 227-232. DOI:10.1007/s 10096-007-0420-3

6. Fuller C, Pellino C, Flagler M, et al (2011) Shiga toxin subtypes display dramatic differences in potency. Infect. Immun 79:1329-1337. DOI: 10.1128/IAI.01182-10 
7. Scheutz F, Teel L, Beutin L et al (2012) Multicenter evaluation of a sequence-based protocol for subtyping Shiga toxins and standardizing Stx nomenclature. J. Clin. Microbiol 50: 2951-2963.DOI: 10.1128/JCM.00860-12

8. Krüger A, Lucchesi P. (2015) Shiga toxins and stx phages: highly diverse entities. Microbiology 161:451-462. DOI:10.1099/mic.0.000003

9. Plunkett G, Rose D, Durfee T, Blattner F (1999) Sequence of Shiga Toxin 2 Phage 933W from Escherichia coli O157: H7: Shiga Toxin as a Phage Late-Gene Product. J Bacteriol 181:1767-1778. DOI: 10.1128/JB.181.6.1767-1778.1999

10. Matsumoto M, Suzuki M, Takahashi M et al (2008) Identification and epidemiological description of enterohemorrhagic Escherichia coli O157 strains producing low amounts of Shiga toxin 2 in Aichi Prefecture, Japan. Jpn. J. Infect. Dis 61:442-445

11. LeJeune J, Abedon S, Takemura K et al (2004) Human Escherichia coli O157: H7 genetic marker in isolates of bovine origin. Emerg Infect Dis 10:1482-1485. DOI:10.3201/eid1008.030784

12. Haugum K, Lindstedt B, Løbersli I et al (2012) Identification of the anti-terminator qO111: H- gene in Norwegian sorbitol-fermenting Escherichia coli O157: NM. FEMS Microbiol Lett 329:102-110. DOI:10.1111/j.1574-6968.2012.02505.x

13. Piedrahita D, Márquez T, Máttar S (2001) Detección de Escherichia coli 0157: H7 en poblaciones porcinas, canal bovina y productos cárnicos en el departamento de Córdoba. Revista MVZ Córdoba, 6:119-126. DOI:10.21897/rmvz.532

14. Franco P, Orozco M, Ramírez L, López L (2013) Determinación de Escherichia coli e identificación del serotipo O157: H7 en carne de cerdo comercializada en los principales supermercados de la ciudad de Cartagena. Revista Lasallista de investigación 10: 9110.http://hdl.handle.net/10567/989

15. Unkmeir A, Schmidt H (2000) Structural analysis of phage-borne stx genes and their flanking sequences in Shiga toxin-producing Escherichia coli and Shigella dysenteriae type 1 strains. Infect Immun 68:4856-4864. DOI:10.1128/IAI.68.9.4856-4864.2000

16. Smith D, Wareing B, Fogg P et al (2007) Multilocus characterization scheme for Shiga toxin-encoding bacteriophages. Appl Environ Microbiol 73:8032-8040. DOI: 10.1128/AEM.01278-07

17. Persson S, Olsen K, Ethelberg S, Scheutz F (2007) Subtyping method for Escherichia coli Shiga toxin (verocytotoxin) 2 variants and correlations to clinical manifestations. J Clin Microbiol 45:2020-2024. DOI:10.1128/JCM.02591-06 
18. Granobles C, Krüger A, Parma and et al (2012) Differences in Shiga toxin and phage production among stx2g-positive STEC strains. Front Cell Infect Microbiol 2: 1-5 DOI: $10.3389 /$ fcimb.2012.00082

19. Muniesa M, Blanco J, De Simon M et al (2004) Diversity of stx 2 converting bacteriophages induced from Shiga toxin-producing Escherichia coli strains isolated from cattle. Microbiology 150:2959-2971.DOI:10.1099/mic.0.27188-0

20. Muniesa M, de Simon, M, Prats G et al (2003) Shiga toxin 2-converting bacteriophages associated with clonal variability in Escherichia coli O157: H7 strains of human origin isolated from a single outbreak. Infect Immun 71:4554-4562. DOI:10.1128/iai.71.8.45544562.2003

21. Tyler J, Mills M, Friedman D (2004) The operator and early promoter region of the Shiga toxin type 2-encoding bacteriophage $933 \mathrm{~W}$ and control of toxin expression. J Bacteriol. 186: 7670-7679. DOI:10.1128/JB.186.22.7670-7679.2004

22. De Sablet T, Bertin Y, Vareille M et al (2008) Differential expression of stx2 variants in Shiga toxin-producing Escherichia coli belonging to seropathotypes A and C. Microbiology, 154:176-186. DOI:10.1099/mic.0.2007/009704-0

23. Ogura Y, Mondal S.I, Islam M.R et al (2015) The Shiga toxin 2 production level in enterohemorrhagic Escherichia coli O157: H7 is correlated with the subtypes of toxinencoding phage. Sci Rep. 5:16663. DOI:10.1038/srep16663

24. Canchaya C, Fournous G, Chibani-Chennoufi S et al (2003) Phage as agents of lateral gene transfer. Curr Opin Microbiol. 6:417-24. DOI:10.1016/s1369-5274(03)00086-9

25. Bobay L, Touchon M, Rocha E (2014) Pervasive domestication of defective prophages by bacteria. Proceedings of the National Academy of Sciences of the United States of America. PNAS.111:12127-32. DOI:10.1073/pnas.1405336111

26. Johansen B, Wasteson Y, Granum P et al (2001) Mosaic structure of Shiga-toxin-2encoding phages isolated from Escherichia coli $\mathrm{O} 157: \mathrm{H} 7$ indicates frequent gene exchange between lambdoid phage genomes. Microbiology. 147:1929-1936. DOI:10.1099/00221287-147-7-1929

27. Gamage S, Patton A, Hanson J, et al (2004) Diversity and host range of Shiga toxinencoding phage. Infect Immun. 72:131-713. DOI:10.1128/IAI.72.12.71317139.2004

28. Shimizu T, Ohta Y, Noda M (2009) Shiga Toxin 2 is specifically released from bacterial cells by two different mechanisms. Infect. Immun 77:2813-2823. DOI:10.1128/IAI.0006009 
29. Karch H, Bielaszewska M (2001) Sorbitol-fermenting Shiga toxin-producing Escherichia coli O157: $\mathrm{H}^{-}$strains: epidemiology, phenotypic and molecular characteristics, and microbiological diagnosis. J Clin Microbiol. 39:2043-2049. DOI:10.1128/JCM.39.6.20432049.2001

30. Allison L (2002) HUS due to a sorbitol-fermenting verotoxigenic E. coli O157 in Scotland. Euro Surveill. 6(44):pii=1955. DOI:10.2807/esw.06.44.01955-en

31. Rosser T, Dransfield T, Allison L, et al (2008) Pathogenic potential of emergent sorbitolfermenting Escherichia coli O157: NM. Infect Immun. 76:5598-5607. DOI:10.1128/IAI.01180-08

32. Koitabashi T, Vuddhakul V, Radu S, et al (2006) Genetic Characterization of Escherichia coli O157: H7/-Strains Carrying the stx2 Gene but Not Producing Shiga Toxin 2. Microbiol Immunol. 50:135-148. DOI:10.1111/j.1348-0421.2006.tb03779.x

33. Rahman M, Nabi A, Asadulghani M, et al (2018) Toxigenic properties and stx phage characterization of Escherichia coli $\mathrm{O} 157$ isolated from animal sources in a developing country setting. BMC Microbiol. 18:98. DOI:10.1186/s12866-018-1235-3

34. Koitabashi T, Cui S, Kamruzzaman M, et al (2008) Isolation and characterization of the Shiga toxin gene (stx)-bearing Escherichia coli O157 and non-O157 from retail meats in Shandong Province, China, and characterization of the O157-derived stx 2 phages. J food protect. 71:706-713. DOI:10.4315/0362-028x-71.4.706

35. Fierz L, Cernela N, Hauser E, et al (2017) Human infections with Shiga toxin-producing Escherichia coli, Switzerland, 2010-2014. Front. Microbiol. 8:1471. DOI: $10.3389 /$ fmicb.2017.01471

36. Melton-Celsa A, O'Brien A, Feng P (2015) Virulence Potential of Activatable Shiga Toxin 2d-Producing Escherichia coli Isolates from Fresh Produce. J food protect. 78: 2085-2088. DOI:10.4315/0362-028X.JFP-15-180.

37. Schmidt H, Scheef J, Morabito S, et al (2000) A new Shiga toxin 2 variant (Stx2f) from Escherichia coli isolated from pigeons. Appl Environ Microbiol.66:1205-1208. DOI:10.1128/aem.66.3.1205-1208.2000

38. Meng Q, Bai X, Zhao A, et al (2014) Characterization of Shiga toxin-producing Escherichia coli isolated from healthy pigs in China. BMC Microbiol., 14:5. DOI:10.1186/1471-2180-14-5.

39. Burgán J, Krüger A, Lucchesi P (2020) Comparable stx2a expression and phage production levels between Shiga toxin-producing Escherichia coli strains from human and bovine origin. Zoonoses Public Health. 67:44-53. DOI:10.1111/zph.12653 
Table 1: Genetic characteristics and virulence genes of the STEC strains.

\begin{tabular}{|c|c|c|c|c|c|c|}
\hline \multirow{2}{*}{ Strain } & \multicolumn{3}{|c|}{ Virulence genes } & \multicolumn{2}{|c|}{$q$ gene alleles } & \multirow{2}{*}{$\operatorname{nin} G$} \\
\hline & Sub Stx2 & saa & hlyA & $q 933$ & $q 0111$ & \\
\hline 102 & $\mathrm{Stx}_{2} \mathrm{~d}$ & + & + & $-\quad t^{a}$ & $+\quad+^{b}$ & + \\
\hline 10610 & $\operatorname{Stx}_{2} \mathrm{a}$ & + & + & $-\quad+^{a}$ & $+\quad+^{b}$ & + \\
\hline 5052 & $\mathrm{Stx}_{2} \mathrm{C}$ & + & + & $-\quad+^{a}$ & $+\quad+^{b}$ & + \\
\hline 600 & $\mathrm{Stx}_{2} \mathrm{c}$ & + & + & $-\quad t^{a}$ & - & + \\
\hline 615 & $\mathrm{Stx}_{2} \mathrm{~d}$ & + & + & $-\quad+^{a}$ & $+\quad+^{b}$ & + \\
\hline N108 & $\mathrm{Stx}_{2} \mathrm{C}$ & + & - & $-\quad t^{a}$ & $+\quad t^{b}$ & $+^{c}$ \\
\hline
\end{tabular}

a. $\quad$ Positive for primers QATG and Q3 and negative for primers Q-stx-f and 595

b. Positive for primers SF1-F and SF1-R, and SF1-R and 595

c. Size of amplified $1200 \mathrm{pb}$ 
Table 2. Primers used to evaluate the late region and sequencing the stx 2 gene of stx phages.

\begin{tabular}{|c|c|c|}
\hline Primer & Sequence & Reference \\
\hline NinG/526 & CACAAGCAATGCGTGGTGTGC & \multirow{2}{*}{$\begin{array}{l}\text { Unkmeir and Schmidt, } \\
2000\end{array}$} \\
\hline 595 & CCGAAGAAAAACCCAGTAACAG & \\
\hline QATG5' $^{\prime}$ & ATGTTCTTATGGTTCACCG & \multirow[t]{2}{*}{ Smith et al 2007} \\
\hline Q3' $^{\prime}$ & TTACGATCGTAAACTATTTTT & \\
\hline Q-stx-f & CGGAGGGGATTGTTGAAGGC & $\begin{array}{l}\text { Unkmeir and Schmidt, } \\
2000\end{array}$ \\
\hline SF1-F & ATACCGTGGCATTTGAAGAGAAGT & \multirow[t]{2}{*}{ Haugum et al 2012} \\
\hline SF1-R & TTTTTAGCAGCCAGTCGTCCA & \\
\hline Q21 & GAAATCCTCAATGCCTCGTTG & Lejeune et al 2004 \\
\hline F4 & GGCACTGTCTGAAACTGCTCCTGT & \multirow[t]{2}{*}{ Scheutz et al 2012} \\
\hline $\mathrm{R} 1$ & ATTAAACTGCACTTCAGCAAATCC & \\
\hline
\end{tabular}






Figure 1. Scheme of the late region of stx phages. Colored arrows show the genes evaluated. Dotted lines show the region amplified by the primers. Taken and adapted from: Burgan et al [39].

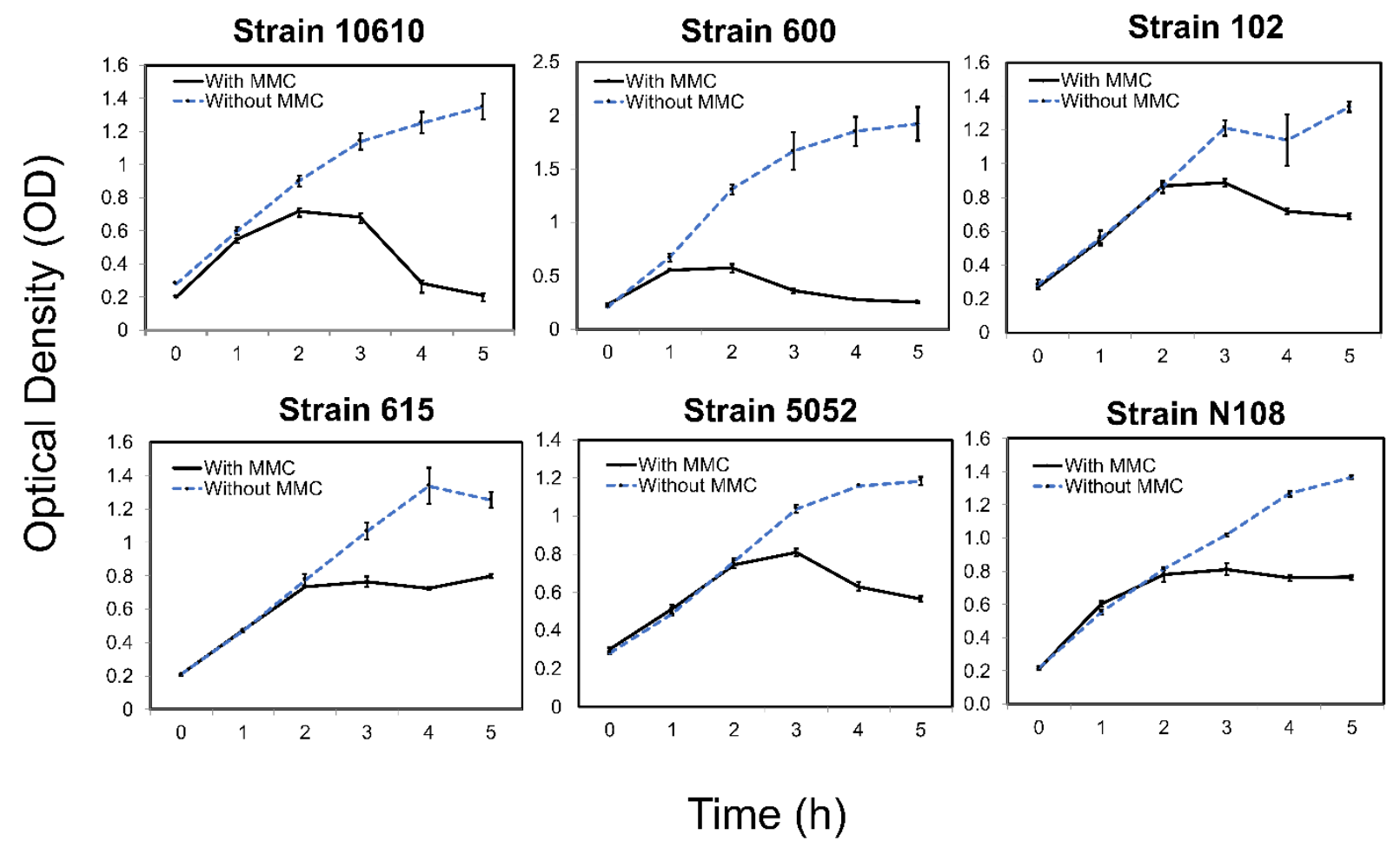

Figure 2. Growth curves/lysis of the strains evaluated in presence/absence of Mitomycin C (MMC). 
bioRxiv preprint doi: https://doi.org/10.1101/2020.07.17.209239; this version posted July 17, 2020. The copyright holder for this preprint (which was not certified by peer review) is the author/funder, who has granted bioRxiv a license to display the preprint in perpetuity. It is made available under aCC-BY-NC-ND 4.0 International license.

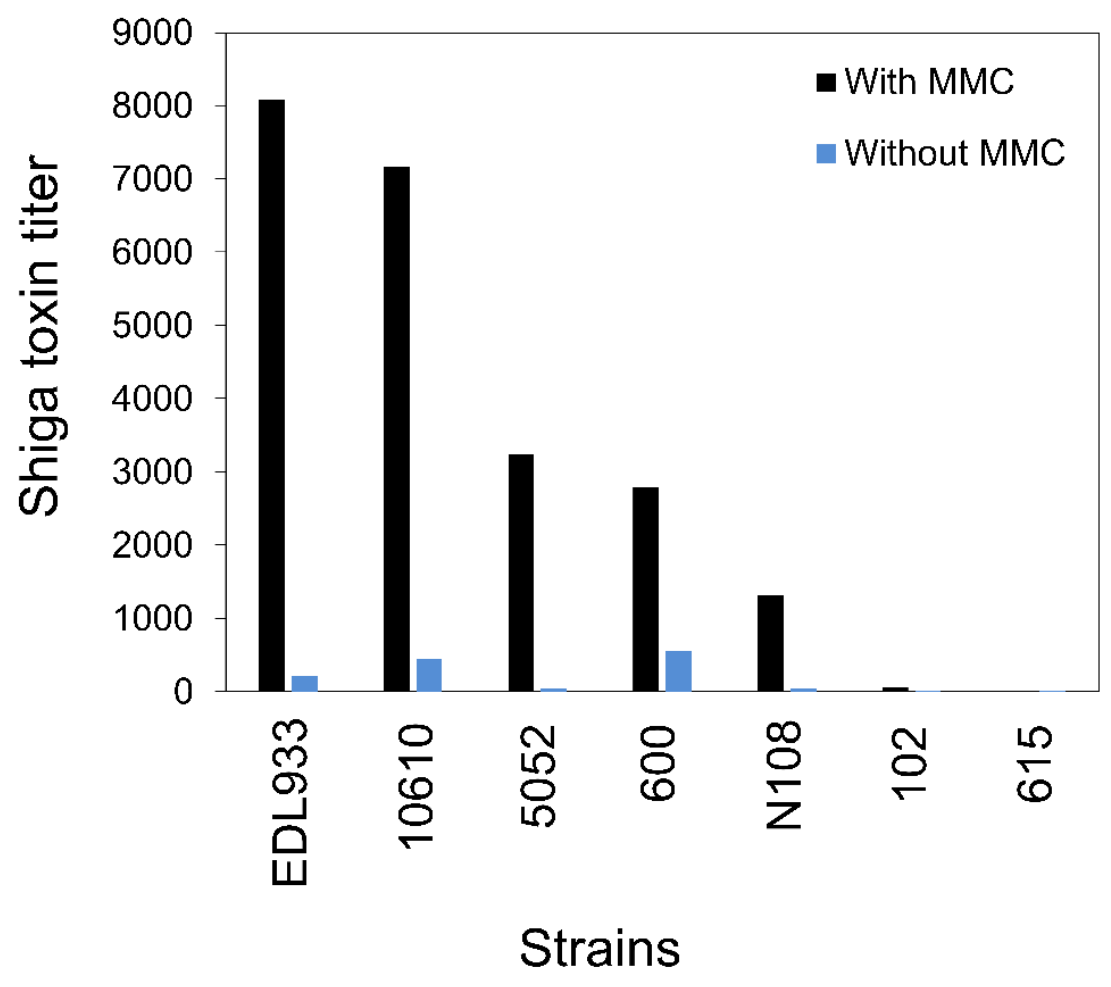

Figure 3. Shiga toxin production of the STEC strains evaluated in presence/ absence of Mitomycin $\mathrm{C}(\mathrm{MMC})$. 


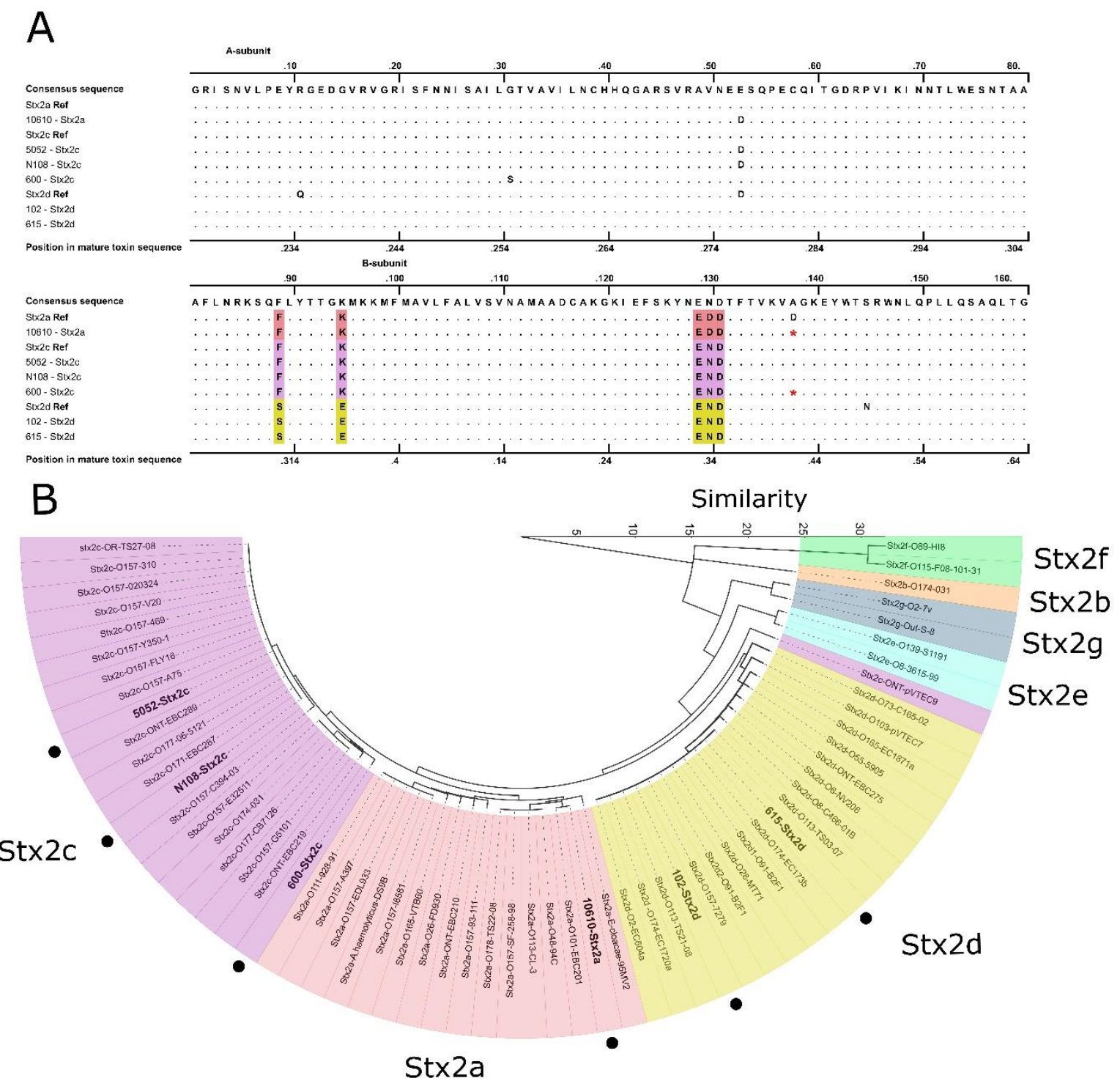

Figure 4: A. Multiple alignment with partial reference sequences of Stx2 subtypes and sequences of Stx 2 obtained in this study. Colors show conserved sites for each subtype. * In that position both Aspartic acid or Alanine may be present. B. The dendrogram shows the groups formed by the reference sequences and the sequences of Stx 2 obtained in this study. 